\title{
Does plastic comb foundation hinder waggle dance communication? ${ }^{1}$
}

\author{
Thomas D. SEELEYa*, Adrian M. REICH ${ }^{\mathrm{a}}$, Jürgen TAUTZ ${ }^{\mathrm{b}}$ \\ a Department of Neurobiology and Behavior, Cornell University, Ithaca, NY 14853, USA \\ $\mathrm{b}$ bee group, Biocenter, Universität Würzburg, Am Hubland, 97074 Würzburg, Germany \\ Received 8 February 2005 - revised 16 March 2005 - accepted 16 March 2005 \\ Published online 13 September 2005
}

\begin{abstract}
In recent years, plastic comb foundation has become widely used by beekeepers but it has not been studied to see if it hinders recruitment communication by reducing the transmission of the comb vibrations produced by bees performing waggle dances. We used laser vibrometry to compare combs built with beeswax foundation vs. plastic foundation in terms of transmission of dance vibrations. We also used behavioral experiments to compare the recruitment effectiveness of dances performed on combs built with beeswax foundation vs. plastic foundation. We found that combs built with plastic foundation are markedly poorer at transmitting the $250 \mathrm{~Hz}$ vibrations produced by dancing bees. Nevertheless, we found no evidence of reduced effectiveness of dances performed on combs built with plastic foundation vs. combs built with beeswax foundation. Evidently, a comb built with plastic foundation provides a fully suitable substrate for waggle dance communication.
\end{abstract}

Apis mellifera / comb vibration / plastic foundation / recruitment communication / waggle dance

\section{INTRODUCTION}

Modern beekeeping is based on four key inventions from the 1800s: movable frame hive, bellows bee smoker, honey extractor, and comb foundation (Crane, 1990). Comb foundation - thin sheets of material embossed with the hexagonal pattern of worker cells on which the bees build their combs - ensures that the bees build planar combs, saves them much wax synthesis during comb building, and inhibits them from rearing drones, by doing away with most of a colony's drone comb. Over the past 20 years, the technology of comb foundation has changed markedly, expanding the types of foundation available to beekeepers. Previously, comb foundation consisted simply of sheets of beeswax that were fitted to wooden frames. Now beekeepers have the options of plastic foundation fitted to wooden frames, and one-piece plastic frames and foundation. Under favorable conditions, bees will build comb on plastic foundation, and many beekeepers have adopted this technology. To date, however, no one has investigated whether frames of comb built with plastic foundation, which is less flexible and more massive than beeswax foundation, provide the bees with a fully suitable substrate for waggle dance communication. If not, then such combs may have negative effects on a colony's recruitment communication and on its honey production. The aim of this study was to see if plastic comb foundation hinders waggle dance communication.

Bees recruit nest mates to rich food sources by performing waggle dances. Each circuit of

\footnotetext{
* Corresponding author: tds5@ cornell.edu
}

${ }^{1}$ Manuscript editor: Stan Schneider 
the dance contains a waggle run during which the bee makes lateral body vibrations at approximately $15 \mathrm{~Hz}$ and thorax/wing vibrations at approximately $250 \mathrm{~Hz}$ (Esch, 1961; Wenner, 1962; Michelsen et al., 1986). The thorax/wing vibrations generate airborne sounds that dance followers detect when adjacent to a waggle dancer (Michelsen, 1993, 2003). Several recent studies indicate that the vibrations produced by a dancing bee are also transmitted via the comb and help followers locate dancers. (1) Dances performed on open empty cells recruit twice as many bees per waggle run compared to dances performed on capped brood cells (Tautz, 1996). (2) The distance from which a dancer attracts followers is greater if the dance occurs on open empty cells rather than capped brood cells (Tautz and Rohrseitz, 1998). (3) Vibrations applied to the rims of open cells are transmitted across the comb and are even amplified through resonance if their frequency is approximately $20 \mathrm{~Hz}$ or $250 \mathrm{~Hz}$ (Sandeman et al., 1996). (4) The 200-300 Hz comb vibrations produced during waggle dances have amplitudes above the detection threshold of the subgenual organ (Kilpinen and Storm, 1997; Nieh and Tautz, 2000). These findings leave little doubt that dancing bees rely, at least in part, on substrateborne vibrations in their recruitment communication. They also suggest that if the transmission of these comb-borne vibrations is hindered, then recruitment is weakened.

In this study, we used laser vibrometry to investigate whether combs built with plastic foundation, relative to combs built with beeswax foundation, are inferior at transmitting $250 \mathrm{~Hz}$ vibrations. In addition, we used behavioral measurements to investigate whether waggle dances produced on combs built with plastic foundation, relative to those produced on combs built with beeswax foundation, are less effective in recruiting bees to a food source.

\section{MATERIALS AND METHODS}

\subsection{Laser vibrometry study in the laboratory: April 2003}

We used 3 frames that were fitted with foundation and then filled (by bees) with beeswax comb:
(1) BW: beeswax foundation in a wooden frame, (2) PW: plastic foundation (Snap-in Pierco) in a wooden frame, and (3) PP: plastic foundation built into a plastic frame (Pierco 1-Piece Frame/Foundation unit). All were full-depth Langstroth frames. In June 2002, the three frames were put in one strong, comb-building colony. It completely filled the frames with beeswax comb and used them for honey storage. In mid September 2002, the honey was extracted from the three frames of comb and in early October, when no nectar was being collected, the combs were returned to the comb-builder colony, which cleaned and repaired them. In mid October, the combs, empty of honey and perfect in form, were retrieved for study.

When taking measurements, we fastened each frame horizontally to a vibration-free table with a Cclamp at each end. The bees built the cells in each comb such that two walls of each hexagonal cell were vertical when the frame was vertical. We displaced the rims of vertical cell walls from the side and in the plane of the comb face, thereby approximating the vibration pattern produced by a bee making vertically-oriented waggle runs on the comb. Displacements were made with a bilayered piezoelectric transducer (BM/ML 60/40/300, Piezomechanik, München) generating $250 \mathrm{~Hz}$ vibrations. Further technical details on the methods of loading vibrations into the combs are given in Sandeman et al. (1996).

The amplitude of cell rim displacement was measured with a laser vibrometer, first at the rim where the displacements were applied (input point) and then at a rim, four cells away (output point, see Fig. 1). Small reflective flags $(0.5 \times 0.5 \mathrm{~mm})$ were attached to the cell rims being measured. Input displacement amplitude was set at $1 \mu \mathrm{m}$ and the resulting output four cells away was measured. Measurements were made only after the signal from the laser vibrometer had stabilized for $30 \mathrm{~s}$. Each measurement was repeated 5 times.

Each frame of comb contained 45 rows of cells. Measurements were made on cells in rows 2, $6,10, \ldots, 22$ using cells one quarter of the horizontal distance across the comb (see Fig. 1). Thus the six measurement points were spread over the comb region that corresponds to the "dance floor" (see Fig. 5.4 in Seeley, 1995). A set of measurements was made for each comb when the comb was $100 \%, 50 \%$, $25 \%$, and $0 \%$ attached to the frame along the sides and bottom. Each comb started out $100 \%$ attached to its frame, and was detached to increasing degrees by melting away 4-mm strips of comb (see Fig. 1). Even when $100 \%$ detached along the sides and bottom of the frame, each comb remained fully attached along the top. 


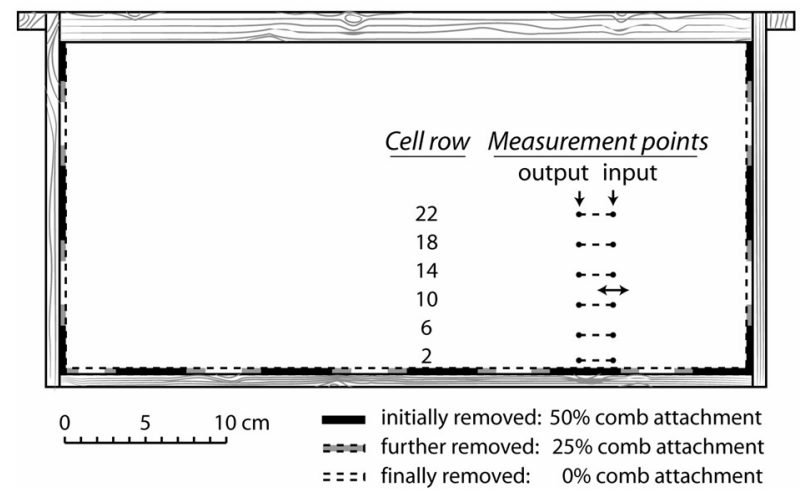

Figure 1. Diagram of a test comb, showing the locations of the vibration input and output measurements, and the way the comb was detached in three stages from the sides and bottom of the frame. The double-headed arrow between the measurement points indicates the displacement direction for the input vibrations.

Table I. The arrangement of the 6 trials of the experiment, with the two sets of combs. BW = beeswax foundation in wooden frame. $\mathrm{PW}=$ plastic foundation in wooden frame. $\mathrm{PP}=$ plastic foundation in plastic frame ("one-piece frame/foundation").

\begin{tabular}{cccccc}
\hline $\begin{array}{c}\text { Comb } \\
\text { set }\end{array}$ & Date & Time & $\begin{array}{c}\text { Test } \\
\text { series }\end{array}$ & $\begin{array}{c}\text { Number of } \\
\text { waggle runs }\end{array}$ & $\begin{array}{c}\text { Number of } \\
\text { recruits }\end{array}$ \\
\hline 1 & 10 July 04 & $11: 20-14: 00$ & BW-PW-PP & 2287 & 107 \\
1 & 11 July 04 & $11: 00-13: 40$ & PW-PP-BW & 2999 & 141 \\
1 & 17 July 04 & $11: 20-14: 00$ & PP-BW-PW & 3437 & 139 \\
2 & 20 July 04 & $11: 20-14: 00$ & BW-PW-PP & 663 & 24 \\
2 & 23 July 04 & $11: 00-13: 40$ & PW-PP-BW & 1714 & 69 \\
2 & 24 July 04 & $11: 40-14: 20$ & PP-BW-PW & 2261 & 111 \\
\hline
\end{tabular}

\subsection{Behavioral study in the field: July 2004}

We set up an observation hive, trained 10 bees to a feeder $350 \mathrm{~m}$ from the hive, and then video recorded the dances of these bees and measured their recruitment of other bees to the feeder. Data were collected three times per day, each time with a different frame of comb as the dance substrate. We then reviewed the video recordings to count the number of waggle runs produced on each type of comb. Using these waggle run counts and the recruit counts, we calculated the waggle dance effectiveness (measured as recruits per waggle run) for the three types of dance substrate.

This experiment utilized six frames of comb, two of each of the three types already mentioned, and prepared as described above. During data collection, one comb at a time was placed in the lower position in a two-frame observation hive which contained one frame of brood comb (upper) and one frame of storage comb (lower) (shown in Seeley, 1995, pp. 71-73). This hive housed a colony consisting of approximately 4000 worker bees and one queen bee. A sheet of queen excluder material between the two frames prevented the queen from laying eggs in the lower comb. A wedge just inside the hive's entrance forced all foragers to enter and exit the hive from one side of the hive. Because returning foragers perform their waggle dances shortly after entering the hive, this wedge established a "dance floor" on one side of the lower comb.

The observation hive colony was established at the Cranberry Lake Biological Station $\left(44^{\circ} 09^{\prime} \mathrm{N}\right.$, $74^{\circ} 48^{\prime} \mathrm{W}$ ), in the Adirondack State Park, in northern New York State. This study site is surrounded by forest and lakes, hence there are few natural food sources for bees, which makes it easy to train bees to forage at a feeder. The hive was mounted in a small hut (see Fig. 4.3 in Seeley, 1995) and the dances were recorded with a camera (Panasonic WV-F250B) whose field of view covered the dance floor. Videotapes were analyzed using a variable-speed videodeck (JVC BR-S525U). Dances were illuminated by the daylight that entered the hut through its translucent roof. We used a feeder that provided scented sucrose solution ad libitum, as described in Seeley (1995). The sucrose solution was generally a $1.50 \mathrm{~mol} / \mathrm{L}$ solution, but at times it was adjusted higher or lower to get the desired level of dancing.

We collected data on 6 days (see Tab. I), using one set of combs (BW, PW, and PP) on the first 


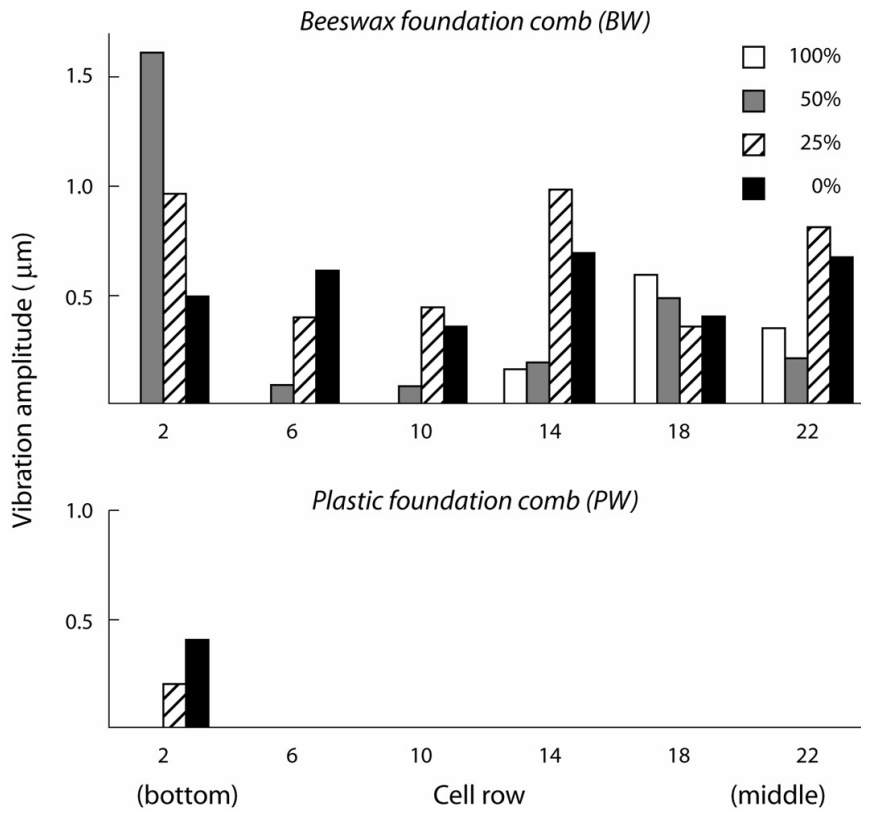

Figure 2. Results of measurements of the amplitudes of cell wall vibrations. Each value is the mean vibration amplitude measured at a point 4 cells from the input point. The input vibration was always a $250 \mathrm{~Hz}$ vibration with $1.0 \mu \mathrm{m}$ amplitude. Measurements were made when comb was $100 \%$, then $50 \%$, then $25 \%$, and finally $0 \%$ attached to the sides and bottom of the frame (see Fig. 1).
3 days and the other set on the second three days. On each day of data collection, we followed a standard protocol. We started with the feeder empty and a standard comb (not a test comb) in the lower position of the observation hive. At 9:00, we filled the feeder and soon bees began visiting it and recruiting nestmates. (Previously, we had trained 10 labeled bees to the feeder. Recruits to the feeder were easily detected as unlabeled bees.) Once recruits began arriving, we began capturing them in zip-lock freezer bags, keeping tallies of the number of recruits captured per 10 min period. This capturing and tallying of recruits continued without interruption until we ended the experiment in the afternoon. As soon as our 10 labeled bees were regularly producing dances for the feeder (by 11:00 or so), we took the lower frame out of the observation and replaced it with the first of the 3 test combs. We then shook the bees off the removed frame onto a board mounted at the hive entrance, whereupon they crawled back into the hive. Next, we gave the colony $20 \mathrm{~min}$ to recover and then we started video recording the dances of the 10 labeled bees. We continued this recording for $40 \mathrm{~min}$, all the while capturing recruits at the feeder. When the 40-min period was over, we repeated the comb swapping procedure described above, replacing test comb 1 with test comb 2 , gave the colony a $20 \mathrm{~min}$ period for recovery, and then resumed video recording the dances, now on a different substrate. After $40 \mathrm{~min}$ of video recording for test comb 2, the entire procedure was repeated for test comb 3 . When this was finished, we replaced test comb 3 with the standard comb, and shut off the feeder to end the experiment for the day. As is shown in Table I, this protocol was performed on 3 days for each of the two sets of test combs, but on each day we presented the test combs in a different order, to control for possible order effects. When we shifted to the second set of combs, we switched to a new set of 10 recruiter bees. Also, part way through the experiment, on 21 July, we added approximately 1500 bees to the observation hive to restore its strength.

On each day, and for each of the three frames of comb, we obtained 4 values of dance effectiveness, one for each 10-min block of the 40 min of data collection for each type of comb. We used the average of these 4 values as our estimate of dance effectiveness for a particular type of comb on a given day. We tested the three frames of comb in each comb set on three days, using a different presentation order each day (see Tab. I), hence we used a complete block design to look for effects of comb type and presentation order. We analyzed our results for each comb set with a two-way analysis of variance (ANOVA) without replication, and so tested for significant differences in dance effectiveness in relation to two factors: comb type and presentation order.

\section{RESULTS}

\subsection{Laser vibrometry study}

Figure 2 shows the results of the vibration amplitude measurements made with the BW 
Table II. Mean values of dance effectiveness (recruits per waggle run) for two sets of combs. For both sets, we show the measured value of dance effectiveness for each combination of comb type and test position.

\begin{tabular}{|c|c|c|c|c|c|c|c|c|c|}
\hline & & & set $1 \mathrm{r}$ & ults & & $\mathrm{Co}$ & $2 \operatorname{set} 2 r$ & ults & \\
\hline & & Posi & $\mathrm{n}$ in tes & eries & & Posi & on in tes & eries & \\
\hline & & $1 \mathrm{st}$ & 2 nd & $3 \mathrm{rd}$ & Row means & $1 \mathrm{st}$ & 2nd & $3 \mathrm{rd}$ & Row means \\
\hline Comb type & BW & 0.027 & 0.042 & 0.071 & 0.047 & 0.023 & 0.048 & 0.066 & 0.046 \\
\hline & PW & 0.022 & 0.054 & 0.060 & 0.045 & 0.022 & 0.050 & 0.088 & 0.053 \\
\hline & PP & 0.027 & 0.058 & 0.061 & 0.049 & 0.032 & 0.062 & 0.063 & 0.052 \\
\hline Column mean & & 0.025 & 0.051 & 0.064 & & 0.026 & 0.053 & 0.072 & \\
\hline
\end{tabular}

and PW combs. In the BW comb, there was good transmission of the $250 \mathrm{~Hz}$ vibrations from input point to output point 4 cells away, though the degree of comb attachment to the frame strongly influenced the pattern of vibration transmission. When the BW comb was $100 \%$ attached to the wooden frame, we found a detectable level of vibration only in the cell rows in the middle of the comb. In contrast, when the BW comb was $0 \%$ or $25 \%$ attached to the wooden frame, we found a detectable and essentially uniform level of vibration in all the cell rows, from bottom to middle of the comb. Curiously, when the comb was $50 \%$ attached to the frame, we found a considerable level of vibration in bottom and middle cell rows, but not in intermediate cell rows.

The results differ markedly for the PW comb, which showed poor transmission of the $250 \mathrm{~Hz}$ vibrations. We found a detectable level of vibration only when the PW comb was little ( 0 or $25 \%$ ) attached to the frame, and even then only in the bottom cell row.

We do not show the results for the PP comb in a graph because they are easily reported in words: for all cell rows, and for all degrees of attachment of comb to frame, we detected no vibrations in cell walls located 4 cells from the input point.

\subsection{Behavioral study}

Table II summarizes our results on the effectiveness of waggle dances performed on different types of comb. We found no effect of comb type on dance effectiveness. The mean dance effectiveness was similar for the three types of comb: 0.05 recruits per waggle run (see Fig. 3 ). ANOVA tests show that the mean values of

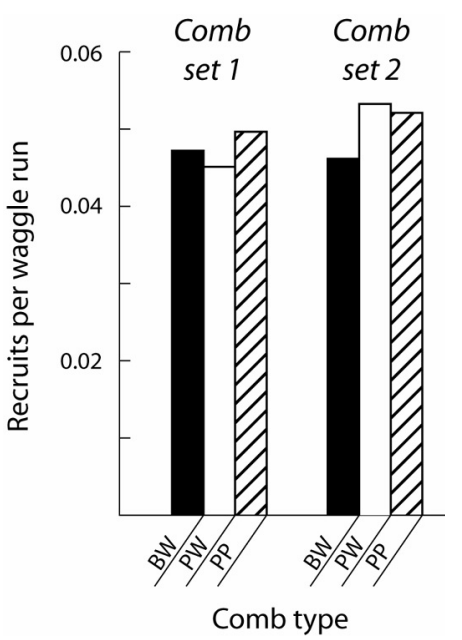

Figure 3. Comparison of the three types of comb with respect to mean dance effectiveness.

dance effectiveness do not differ significantly among comb types, both for comb set $1\left(\mathrm{~F}_{2,4}=\right.$ $0.16, P>0.90)$ and for comb set $2\left(\mathrm{~F}_{2,4}=2.94\right.$, $P>0.25)$.

We did find, however, a strong effect of position in the test series on dance effectiveness (see Fig. 4). Regardless of comb type, the comb presented at the start had a lower mean dance effectiveness (approx. 0.025 recruits per waggle run) than the comb presented in the middle (approx. 0.050 recruits per waggle run), which in turn had a lower mean dance effectiveness than the comb presented at the end (approx. 0.068 recruits per waggle run). ANOVA tests show that the mean values of dance effectiveness differ significantly among test positions, both for comb set $1\left(\mathrm{~F}_{2,4}=21.95, P<0.01\right)$ and for comb set $2\left(\mathrm{~F}_{2,4}=8.85, P<0.04\right)$. 


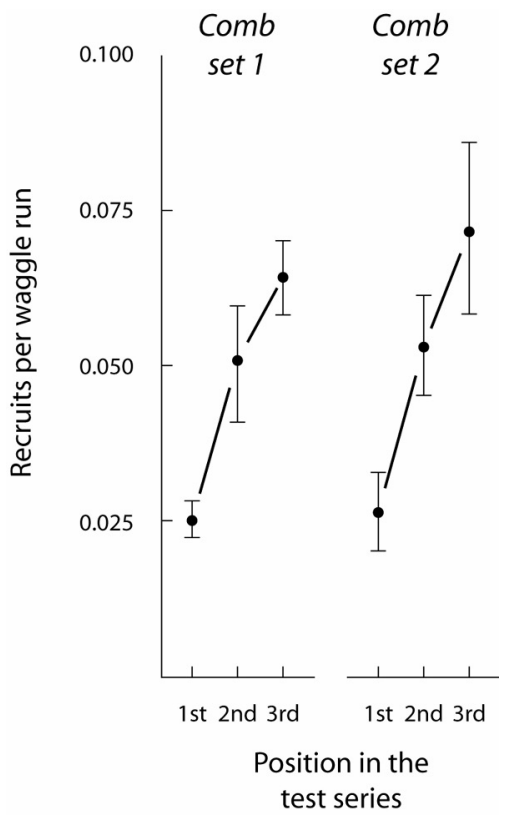

Figure 4. Comparison of the three positions in the test series with respect to dance effectiveness.

The results described so far are based on bees performing dances that were illuminated by daylight for video recording. Having found no effect of comb type on dance effectiveness, we wondered if this was because the dances were performed in daylight. Perhaps dance followers had easily found dancing bees by seeing their movements rather than by detecting their comb vibrations. If so, then differences among the comb types in vibration transmission would not matter.

To see if we had obscured an effect of comb type on dance effectiveness by studying dances performed under lighted conditions, we performed another test with the combs of comb set 1 . For each comb, we checked whether dances were less effective when performed on a darkened vs. a lighted dance floor. We reasoned as follows. Hypothesis: dances on combs with plastic foundation were as effective as dances on combs with beeswax foundation because dances produced on a lighted dance floor are unusually easy to find. Prediction: dances on combs with plastic foundation will be less effective on a darkened dance floor than on a lighted one. To check this prediction, we
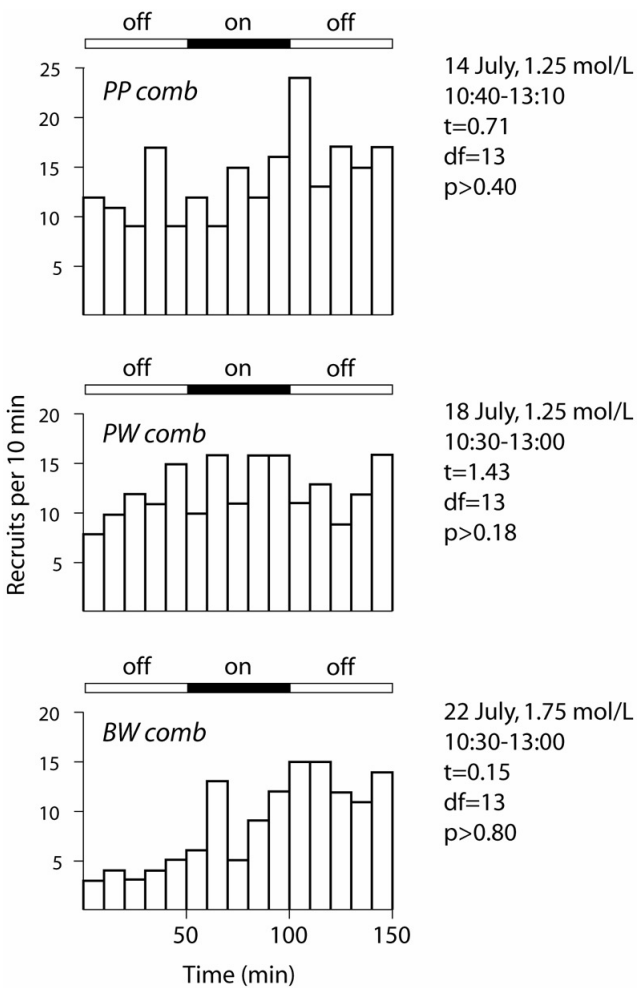

Figure 5. Results of tests for effect of light on dance effectiveness. The number of bees recruited every 10 min by 10 dancers visiting a feeder was measured for a $150 \mathrm{~min}$ period. For the first $50 \mathrm{~min}$ and last $50 \mathrm{~min}$, the observation hive was not covered, so the dances were performed in daylight. For the middle $50 \mathrm{~min}$, the observation hive was covered, so the dances were performed in darkness. The same result was found for all three types of comb: no difference in the mean number of recruits per $10 \mathrm{~min}$ between the cover-off and cover-on times.

made recruitment measurements under constant conditions except that part of the time the observation hive's cover was off (dance floor lighted) and part of the time the cover was on (dance floor darkened). The results are shown in Figure 5. For all three types of comb, we found no sign of reduced dance effectiveness with darkened dance floor.

\section{DISCUSSION}

Do combs built with plastic foundation hinder the bees' ability to communicate with waggle dances? Evidently, they do not. In our 
behavioral tests, we found no sign whatsoever of reduced dance effectiveness when bees danced on combs built with plastic foundation relative to combs built with beeswax foundation. Because we measured the effectiveness of dances performed in daylight in an observation hive, we must ask whether our conclusion (no hindrance of dance communication by plastic foundation) also holds true for dances performed in darkness in a normal hive.

Two lines of evidence indicate that we did not get falsely negative results. The first is that previous investigators of substrate effects on waggle dance communication (Tautz, 1996; Tautz and Rohrseitz, 1998) also studied dances performed in daylight and they found strong substrate effects, e.g., differences in recruitment success between dances performed on open cells vs. sealed cells. Clearly, substrate differences can influence dance effectiveness even when dances are performed in daylight. The second line of evidence is the finding in the present study that when we darkened the dance floor, we found no drop in recruitment by bees dancing on combs built with plastic foundation. If these combs were inferior substrates for dances performed in darkness, then we should have seen reduced recruitment when we darkened the dance floor, but we did not. We believe, therefore, that our main conclusion combs built with plastic foundation do not hinder waggle dance communication - is a true negative, not a false one.

The finding that combs built with plastic foundation provide a fully suitable substrate for waggle dances was, at first, surprising because our laser vibrometry study revealed much poorer transmission of $250 \mathrm{~Hz}$ vibrations in plastic-based vs. beeswax-based combs. How can we resolve this seeming conflict between the two parts of our study? The most likely explanation is that dance followers used frequencies other than the $250 \mathrm{~Hz}$ that we used in our laser vibrometry study. When performing a waggle dance, a bee produces not only $250 \mathrm{~Hz}$ vibrations by activating her thoracic musculature, but also $15 \mathrm{~Hz}$ vibrations by swinging her body side to side. We suggest that dance followers use mainly the $15 \mathrm{~Hz}$ vibrations to orient to dancers. We chose $250 \mathrm{~Hz}$ displacements for our laser vibrometry study because prior investigations found that unframed combs have a striking peak in transmission effectiveness
(Fig. 7 in Sandeman et al., 1996) and a sharp drop in impedance (Fig. 25 in Rohrseitz, 1998) for $250 \mathrm{~Hz}$ vibrations. These same studies also found, however, that framed combs have poor transmission and high impedance of $250 \mathrm{~Hz}$ vibrations, but have good transmission and low impedance of 15-20 Hz vibrations (Fig. 10 and 12 in Sandeman et al., 1996, and Fig. 26 in Rohrseitz, 1998). If a framed comb is freed from the frame on bottom and sides, then there is improved transmission effectiveness of $250 \mathrm{~Hz}$ vibrations (a finding confirmed by our results, see Fig. 2), but even so it remains below the transmission effectiveness of $15-20 \mathrm{~Hz}$ vibrations. In hindsight, it is regrettable that we studied the effects of plastic foundation on vibration transmission using only $250 \mathrm{~Hz}$ stimuli. This work needs to be extended using $15 \mathrm{~Hz}$ stimuli. We predict that the transmission of $15 \mathrm{~Hz}$ vibrations will not differ between framed combs built with beeswax vs. plastic foundation.

Besides testing the effects of plastic foundation on dance communication, our behavioral study also yielded a curious finding about the waggle dance system of bee communication: its effectiveness changed markedly over the course of a day. As is shown in Figure 4, we found that dances performed early in the day were only one third as effective in getting recruits to the feeder compared to dances performed later in the day. This change in dance effectiveness appears robust, for we found the same pattern on all 6 days of data collection (Tab. II). How did this change in dance effectiveness arise? Perhaps it reflects a gradual activation of the study colony's foragers over the course of a day, so that more bees were ready to follow dances later in the day. Another possibility, however, is that bees that had followed a dance for the feeder and left the hive to search for it somehow found it easier to find the feeder later in the day. Future studies are needed to see if the daily increase in dance effectiveness that we found is a typical, and if so, to determine whether it reflects a gradual "waking up" of the foragers in a honey bee colony.

\section{ACKNOWLEDGMENTS}

This project was supported by the National Research Initiative of the USDA Cooperative State Research, Education and Extension Service, grant 
number 2004-35302-14838, and by the Alexander von Humboldt Foundation, which has provided TDS with a Research Award. We are also grateful to Dr. Stephen A. Teale, director of the Cranberry Lake Biological Station, for continuing to provide us with space and facilities at this lovely field station.

Résumé - Les fondations en plastique gênentelles la communication dansée ? Ces dernières années les fondations en plastique se sont largement répandues chez les apiculteurs, mais aucune étude n'a été faite pour savoir si elles gênaient le recrutement en réduisant la transmission des vibrations du rayon produites par les abeilles qui exécutent la danse frétillante. On sait que les danseuses se fient, au moins partiellement, aux vibrations du rayon pour communiquer les sources de nourriture, probablement parce que ces vibrations aident les abeilles à localiser les danseuses dans l'obscurité de la ruche. Nous avons étudié trois types de rayon: (i) rayon construit sur une fondation en cire d'abeilles fixée à un cadre en bois (BW), (ii) rayon construit sur une fondation en plastique fixée à un cadre en bois (PW), (iii) rayon construit sur une pièce unique fondation/ cadre en plastique (PP).

Nous avons utilisé la vibrométrie laser pour comparer les trois types de rayons en termes de transmission des vibrations produites par les danses. Les rayons construits sur une fondation en plastique transmettaient mal les vibrations de $250 \mathrm{~Hz}$. Par contre ceux construits sur une fondation en cire d'abeille les transmettaient très bien, en particulier lorsque le rayon était partiellement détaché du cadre en bois (Fig. 2).

Nous avons réalisé une étude comportementale pour comparer l'efficacité du recrutement (ER) des danses sur les différents types de rayons. L'ER a été mesurée en termes de nombre d'abeilles recrutées sur un nourrisseur à $350 \mathrm{~m}$ par un trajet frétillant produit pour le nourrisseur. Nous n'avons trouvé aucun effet (Fig. 3). Les trois types de rayon ont donné la même valeur moyenne d'efficacité : environ 0,05 recrue par trajet frétillant. Quel que soit le type de rayon, l'ER différait notablement selon que c'était le premier, le second ou le troisième rayon utilisé dans la journée. Les danses exécutées en fin de journée avaient une plus grande efficacité que celles exécutées plus tôt (Fig. 4). Nous suggérons que l'augmentation de l'efficacité au cours de la journée reflète une activation graduelle des butineuses de la colonie, si bien que les ouvrières sont plus nombreuses à suivre les danses plus tard dans la journée.

Que nous n'ayons pas trouvé un effet du type de rayon sur l'ER peut être dû au fait que notre expérimentation a été réalisée en lumière du jour. Cela a pu aider les abeilles à trouver les danseuses en voyant leurs mouvements plutôt qu'en sentant leurs vibrations. Nous avons testé cette hypothèse en cherchant si les danses exécutées sur les rayons PW et $\mathrm{PP}$, qui ont une faible transmission des vibrations de $250 \mathrm{~Hz}$, voyaient leur efficacité diminuer lorsque le plancher des danses était assombri. Nous n'avons trouvé aucun signe montrant une réduction de l'ER (Fig. 5). Nous en concluons que l'absence d'effet du type de rayon sur l'efficacité des danses est un résultat négatif vrai et non un faux. Il est clair qu'un rayon construit sur une fondation en plastique constitue un substrat tout à fait adapté à la communication par la danse frétillante.

Apis mellifera / vibration du rayon / fondation en plastique / communication / recrutement / danse frétillante

Zusammenfassung-Behindert eine Kunststoffmittelwand der Bienewabe die Tanzkommunikation? In den letzten Jahren werden von Imkern zunehmend Mittelwände aus Kunststoff für den Ausbau von Waben eingesetzt. Es war bisher nicht untersucht, ob solche Mittelwände die Rekrutierung zu Futterplätzen beeinträchtigen, etwa indem sie die von den Bienen beim Schwänzeltanz erzeugten Schwingungen reduzieren. Es ist bekannt, dass tanzende Bienen für ihre Futterkommunikation zumindest teilweise auf über die Wabe weitergeleiteten Schwingungen angewiesen sind. Vermutlich helfen diese Schwingungen tanzenden Bienen in der Dunkelheit des Nestes zu lokalisieren. Wir untersuchten die drei folgenden Wabenarten: Auf Mittelwänden oder auf Plastikmittelwänden gebaute und in ein Holzrähmchen eingepasste Waben (BW bzw. PW), und eine aus einem Stück bestehend Einheit aus Mittelwand und Rähmchen ausgebaute Wabe (PP).

Wir benutzten Laservibrometrie, um die drei Wabentypen auf ihre Weiterleitungseigenschaften für die beim Tanz entstehenden Vibrationen zu untersuchen. Auf Plastikmittelwänden gebaute Waben leiteten Vibrationen mit einer Frequenz von $250 \mathrm{~Hz}$ schlecht weiter. Waben mit Wachsmittelwänden leiteten diese Frequenz dagegen gut weiter, besonders wenn sie teilweise nicht mit dem umgebenden Rähmchen verbunden waren (Abb. 2). Anhand einer Verhaltensuntersuchung verglichen wir die Effizienz der Rekrutierung von Bienen durch die Tanzkommunikation auf den drei Wabentypen. Als Rekrutierungseffizienz wurde die Anzahl der zu einer Futterstelle angeworbenen Bienen pro gezeigtem Schwänzeltanz bestimmt. Wir fanden keinen Einfluss des Wabentypes auf die Rekrutierungseffizienz (Fig. 3); auf allen drei Wabentypen war diese ähnlich und betrug ungefähr 0.05 rekrutierte Bienen pro Schwänzellauf. Wir fanden allerdings einen Positionseffekt in der Testserie. Unabhängig von dem Wabentyp gab es deutliche Unterschiede in der Effizienz der Tänze je nachdem ob diese auf der ersten, zweiten oder dritten der im Verlauf des Tages genutzten Waben stattfanden.

Später am Tag durchgeführte Tänze waren effektiver als früh am Tag durchgeführte (Fig. 4). Wir nehmen an, dass dieser Anstieg in der Tanzeffektivität im Tagesverlauf auf die allmähliche Aktivierung der Sammlerinnen in einem Volk zurückzuführen ist, 
wonach später am Tag mehr Sammlerinnen bereit wären den Tänzen zu folgen. Es hätte sein können, dass ein Wabeneffekt deshalb nicht gefunden wurde, weil die Experimente unter Tageslichtbedingungen durchgeführt wurden unter denen es für die Bienen leicht gewesen sein könnte, Tänzerinnen auch ohne Wabenvibrationen anhand ihrer Bewegungen zu finden. Wir untersuchten daher bei verdunkeltem Tanzboden, ob die Tanzeffektivität auf PP Waben mit ihrer schlechteren Weiterleitung für Vibrationen von $250 \mathrm{~Hz}$ geringer war als bei PW Waben. Hierbei ergab sich kein Anzeichen einer verringerten Tanzeffektivität (Fig. 5) woraus sich schließen lässt, dass das negative Ergebnis über einen Wabeneffekt ein wahres, nicht falsches Negativergebnis darstellt. Offensichtlich stellt eine auf einer Plastikmittelwand gebaute Wabe einen vollständig geeigneten Untergrund für die Schwänzeltanzkommunikation dar.

Apis mellifera / Wabenvibration / Plastikmittelwände / Futterkommunikation / Schwänzel$\tan z$

\section{REFERENCES}

Crane E. (1990) Bees and beekeeping, Cornell University Press, Ithaca, New York.

Esch H. (1961) Über die Schallerzeugung beim Werbetanz der Honigbiene, Z. Vgl. Physiol. 45, $1-11$.

Kilpinen O., Storm J. (1997) Biophysics of the subgenual organ of the honeybee, Apis mellifera, J. Comp. Physiol. A 173, 135-141.
Michelsen A. (1993) The transfer of information in the dance language of honeybees: progress and problems, J. Comp. Physiol. A 181, 309-318.

Michelsen A. (2003) Signals and flexibility in the dance communication of honeybees, J. Comp. Physiol. A 189, 165-174.

Michelsen A., Kirchner W.H., Lindauer M. (1986) Sound and vibrational signals in the dance language of the honeybee, Behav. Ecol. Sociobiol. 18, 207-212.

Nieh J.C., Tautz J. (2000) Behaviour-locked signal analysis reveals weak $200-300 \mathrm{~Hz}$ comb vibrations during the honeybee waggle dance, J. Exp. Biol. 203, 1573-1579.

Rohrseitz K. (1998) Biophysikalische und ethologische Aspekte der Tanzkommunikation der Honigbienen (Apis mellifera carnica Pollm.), $\mathrm{Ph} . \mathrm{D}$. thesis, Universität Würzburg.

Sandeman D.C., Tautz J., Lindauer M. (1996) Transmission of vibration across honeycombs and its detection by bee leg receptors, J. Exp. Biol. 199, 2585-2594.

Seeley T.D. (1995) The wisdom of the hive, Harvard University Press, Cambridge, Massachusetts.

Tautz J. (1996) Honeybee waggle dance: recruitment success depends on the dance floor, J. Exp. Biol. 199, 1375-1381.

Tautz J., Rohrseitz K. (1998) What attracts honeybees to a waggle dancer? J. Comp. Physiol. A 183 , 661-667.

Wenner A. (1962) Sound production during the waggle dance of the honeybee, Anim. Behav. 10, 79-95. 